\title{
Age constraints on the lithosphere beneath the Halls Creek mobile belt and implications for diamonds of the Argyle lamproite deposit
}

\author{
A. Luguet (1,2), D.G. Pearson (1), A.L. Jaques (3), C.B. Smith (4), G.P. Bulanova (5), G. \\ Carter (6), S. Roffey (6), M.J. Rayner (7) and J.-P. Lorand (8)
}

\begin{abstract}
(1) Department of Earth Sciences, University of Durham, UK, (2) Steinmann Institute, Endogene Prozesse, Universitat Bonn, Germany (ambre.luguet@uni-bonn.de), (3) Geoscience Australia, Canberra ACT, Australia, (4) Rio Tinto Mining and Exploration Ltd., London, UK, (5) University of Bristol, UK, (6) Rio Tinto Exploration Pty. Ltd., Perth, Australia, (7) Argyle Diamond Mines Ltd, West Perth, Australia, (8) Museum National d'Histoire Naturelle, Paris, France.
\end{abstract}

\section{Introduction}

The world-class diamond mine hosted by the Argyle AK1 lamproite is the only major diamond deposit found in an Early Proterozoic mobile belt, the Halls Creek Orogenic belt (HCOB) at the southeast margin of the Kimberley craton in Western Australia (Fig. 1). It is often considered to be an anomalous diamond-deposit as economic diamond-bearing kimberlite pipes are usually found "on-craton" whereas "off-craton" kimberlites or alkaline ultrabasic rocks are generally diamond-barren, presumably having been derived from shallower depths and thus having sampled the lithosphere in the graphite stability field.

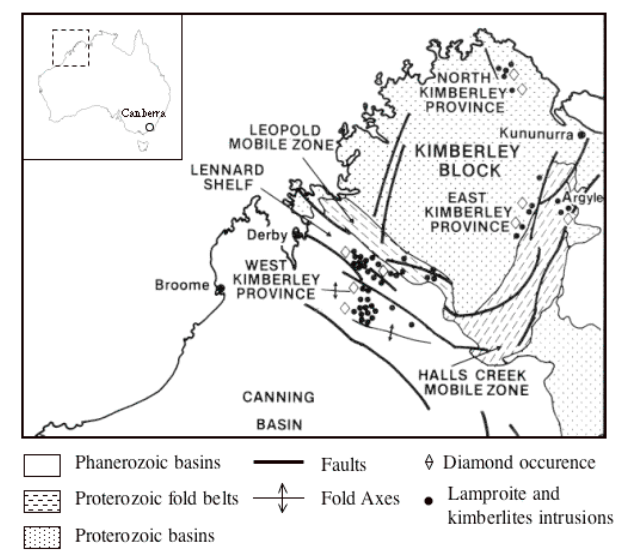

Figure 1: Map of Western Australia showing the location of the diamond occurrences including the Argyle diamond mine. Map after Jaques et al., (1986).

The age of the lithospheric mantle under Argyle is only poorly constrained. Archean lithosphere beneath the Kimberley craton has long been suspected but no rocks of Archean age have been found. The Sm-Nd model ages of the Argyle lamproite argue derivation of the lamproite from an enriched mantle of Early Proterozoic to Late Archean age ( $>2 \mathrm{Ga}$, Jaques et al., 1989). In addition, U-Pb SHRIMP dating of detrital zircons from the Paleoproterozoic metasediments in the western zone of the HCOB indicate ages between 2.53.6 Ga, suggesting the presence of Archean basement (Page and Sun, 1991) but the source of the zircons is unknown. More recently, Re-Os isotopic dating of 2 Argyle peridotite xenoliths indicated an apparent Archean age $(>2.55 \mathrm{Ga})$ for the mantle root under Argyle (Graham et al., 1999). However, the $\mathrm{T}_{\mathrm{MA}}$ ages calculated by Graham et al., (1999) are likely to overestimate the "real" age of the mantle root formation since the $\operatorname{Re}$ contents of the 2 studied xenoliths obviously bear metasomatic imprints.

The age of the lithospheric mantle beneath both the orogenic belt and adjacent Kimberley Craton has been a matter of debate since discovery of the deposit and resolution of this issue has important implications not only for diamond genesis and exploration models but also for our understanding of the deep lithospheric architecture beneath "mobile" belts. In this study, in order to obtain a clearer picture of the lithospheric root geometry under Argyle in terms of depths and age, we present whole rock major and trace element geochemistry plus Re-Os isotope and PGE systematics of a suite of 23 mantle xenoliths (including 19 newlydiscovered xenoliths) sampled by the Argyle lamproite. The coupling of Re-Os isotopes with the PGE systematics allows us to assess the origin of Re (primary or added by the lamproite for example) and therefore provides a more reliable Re-Os age estimate that is consistent with conclusions arrived at using petrological and major element geochemical constraints. A late Archean age is strongly supported, making the Argyle deposit "normal" in terms of the mantle that it samples. 


\section{Mineralogy and Petrology of the Argyle peridotite xenoliths}

The xenoliths range in size from $8-12 \mathrm{~cm}$ and commonly show strong reaction rims with the host lamproite. They are coarse-grained garnet lherzolites and granet-harzburgites that have experienced extensive alteration. This has led to partial to complete transformation of olivine into lizardite, montmorillonite and talc, and alteration of pyroxenes into talc, calcite and/or tremolite (diopside). Garnets have been entirely replaced by symplectic intergrowths of fine grained Al-Cr spinel, pyroxene and secondary silicates showing a large variety of textures. Accessory minerals consist of (1) microdiamonds occurring as irregular unresorbed octahedron-based shapes and macled octahedrons (Hall and Smith, 1984), found in 14 xenoliths and (2) base-metal sulfides of hydrothermal origin present as tiny grains dispersed in the serpentinised matrix or as veinlets crosscutting the matrix.

Major element compositions $\left(\mathrm{Al}_{2} \mathrm{O}_{3}=0.5-1.9\right.$ wt.\%, $\mathrm{CaO}=0.2-2.3 \mathrm{wt} . \%)$ as well as mineral chemistry (Olivine $\mathrm{Mg \# =91.5-92.5)}$ are typical of strongly to moderately refractory mantle peridotites (Pearson and Wittig, 2008). The Argyle peridotites also define a negative $\mathrm{MgO}$ vs. $\mathrm{SiO}_{2}$ trend, overlapping those of other cratonic peridotites as well as fore-arc peridotites. The concentration ranges of the LILE, REE and HFSE in the Argyle peridotites $(0.06-350 x$ Primitive mantle (PM) -normalizing values: McDonough and Sun, 1995) are inconsistent with the major element depletion and the refractory mineral compositions and rather reflect lamproite addition by infiltration and/or earlier metasomatism enrichment (Jaques et al., 1990). In contrast, the HREE do not vary with the LREE suggesting that the HREE concentrations are only slightly disturbed, likely preserving melting trends and information relative to the pressure and conditions of melting (Canil, 2004). Ytterbium and Lutetium abundances display a weak positive correlation with $\mathrm{Al}_{2} \mathrm{O}_{3}$ contents for 18 samples $(\mathrm{r}=0.56)$ but 6 samples, the same for the two binary diagrams, show slight to strong enrichment in $\mathrm{Yb}$ and $\mathrm{Lu}$ for a given $\mathrm{Al}_{2} \mathrm{O}_{3}$ contents. Ytterbium concentrations in the other 18 samples range from 0.03-0.17 ppm $\left(\mathrm{Yb}_{\mathrm{PM}}=0.09-0.4\right)$ while Lu concentration range from 0.07 to $0.029 \mathrm{ppm}$. Such low $\mathrm{Yb}$ and $\mathrm{Lu}$ concentrations reflect low pressure melting $(<3 \mathrm{Gpa})$, with most of the melting occurring in the spinel stability field (Canil, 2004; Pearson and Wittig, 2008). Geothermobarometric estimates available for 10 of the 23 samples indicate equilibration within the diamond stability field at 150 $180 \mathrm{~km}$ depth for both diamondiferous and nondiamondiferous xenoliths, confirming the presence of deep lithosphere in this region (Jaques et al., 1990).

\section{Highly Siderophile Elements and Re-Os isotopic} systematics of the Argyle peridotite xenoliths

Whole-rock highly siderophile element (HSE) concentrations range from 1.6-13 ppb Os, 1.7-7.8 ppb
Ir, 1.3-38.4 ppb Ru, 1.0-25.1 ppb Pt, 0.3-15.3 ppb Pd and 0.06-1.02 ppb Re. HSE abundances do not correlate with any major element-based fertility index (e.g. $\mathrm{Al}_{2} \mathrm{O}_{3}$ ), trace elements (e.g. $\mathrm{Ba}, \mathrm{Rb}, \mathrm{La}, \mathrm{Yb}$ ), temperature and pressure of equilibration. $\mathrm{Os}, \mathrm{Ir}, \mathrm{Ru}$ and $\mathrm{Pt}$ vary sympathetically suggesting similar minerals to control these compatible HSE in the peridotites. In some samples, moderate depletions of $\mathrm{Pt}$ exist. In contrast, $\mathrm{Pd}$ and $\mathrm{Re}$ behave independently of the compatible HSE and of each other. Overall, CIchondrite-normalised HSE patterns do not resemble typical mantle residues that have experienced moderate to high degrees of partial melting (Pearson et al., 2004). Specifically, the Argyle peridotites show enrichment of $\mathrm{Re}$, sometimes associated with $\mathrm{Pd}$ enrichment, likely postdating the partial melting. When correcting for Re in-growth since the $1178 \mathrm{Ma}$ eruption age of the lamproite ( $\mathrm{Rb}-\mathrm{Sr}$ phlogopite-whole rock; Pidgeon et al., 1989), Re-depletion ages vary from 1 to $3.1 \mathrm{Ga}$ with a peak between $2.2-2.8 \mathrm{Ga}$, clearly indicating the presence of Archean mantle at depth beneath this region (Fig. 2).

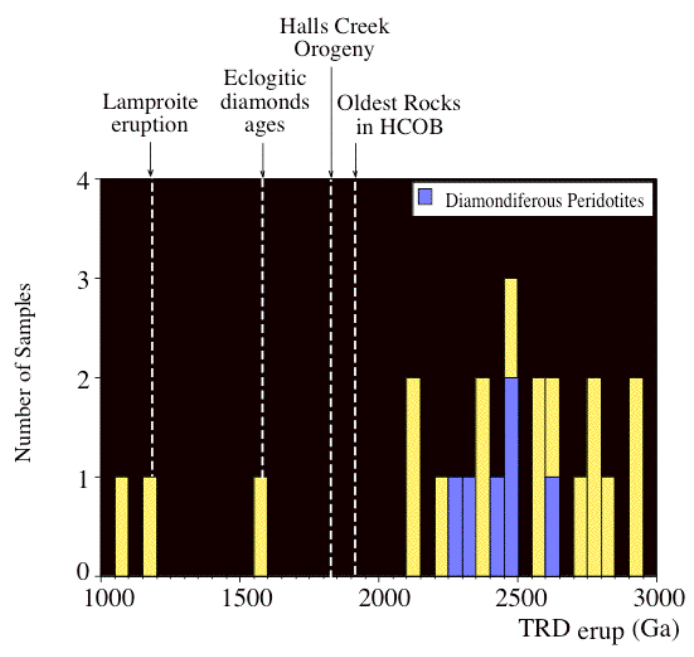

Figure 2: Re-depletion ages of the diamondiferous (blue) and non-diamondiferous (yellow) Argyle peridotite xenoliths.

No systematic variation of Re-depletion ages was observed with depth of equilibration although our sample set samples only a limited depth range, at the very base of the lithosphere. The combined platinum group element and Re-Os systematics of our samples show that the peridotites have experienced metasomatic siderophile element addition, making previous $\mathrm{T}_{\mathrm{MA}}$ model ages (Graham et al., 1999) unreliable.

\section{Discussion and Conclusion}

The mineral chemistry and bulk rock major element compositions of the Argyle peridotite suite resemble those of the Late Archean Somerset Island peridotite suite studied by Irvine et al. (2003). In addition, moderate depletions in $\mathrm{Pt}$ in the whole-rock HSE patterns make these peridotites distinct from Phanerozoic and Proterozoic melt residues but are 
analogous to the relative PGE depletions observed in the Late Archean Somerset Island peridotites. These observations combined with the fact that 10 of the peridotites give minimum Re-depletion ages in excess of $2.5 \mathrm{Ga}$ provide the first firm indication that the lithospheric mantle beneath the HCOB is Archean in age. The Archean Re depletion ages are significantly older than the circa 1.8 to $1.9 \mathrm{Ga}$ crustal basement age implying that the HCOB is a shallow feature that may have been transported laterally over older cratonic lithosphere. Our data indicate that the reason for anomalously thick lithosphere beneath crust of midProterozoic age is due to the underlying ancient, cold, stable Archean lithospheric mantle. This is another example of crust-mantle decoupling and indicates that we should exercise caution in estimating the extent of Archean lithosphere based on outcrops of Archean crustal rocks. In addition, the existence of thick, cold lithospheric mantle beneath this area today, as inferred by seismic tomography (Simons et al., 1999; Fishwick et al., 2005) implies survival of the cratonic root since at least the late Archean. Similarly, the existence of Archean diamondiferous peridotites (this study) together with Proterozoic eclogitic diamonds (1580 Ma: Richardson et al., 1986) in the Argyle pipe suggest that conditions for diamond stability existed in the Argyle cratonic root for at least $1400 \mathrm{Ma}$, slightly longer than the modelled survival of diamonds in cratonic roots (O’Neill and Moresi, 2003).

\section{References}

Canil, D., 2004. Mildly incompatible elements in peridotites and the origins of mantle lithosphere. Lithos 77, 375393.

Graham, S., Lambert, D.D., Shee, S.R., Smith, C.B., Reeves, S., 1999. Re-Os isotopic evidence for Archean lithospheric mantle beneath the Kimberley block, Western Australia. Geology 27 (5), 431-434.

Fishwick, S., Kennett, B.L.N., Reading, A.M., 2005. Contrasts in lithospheric structure within the Australian craton-insights from surface wave tomography. Earth Plane. Sci. Lett. 231, 163-176.

Irvine, G.J., Pearson, D.G., Kjarsgaard, B.A., Carlson, R.W., Kopylova, M.G., Dreibus, G., 2003. A Re-Os isotope and PGE study of kimberlite-derived peridotite xenoliths from Somerset Island and a comparison to the Slave and Kaapvaal cratons. Lithos 71, 461-488.
Hall, A.E., Smith, C.B., 1984. Lamproite diamonds-are they different? In Kimberlite Occurence and Origin: A basis for conceptual models in exploration, Publication $\mathrm{N}^{\circ} 8$ (Eds J.E. Glover and P.G. Harris), pp. 167-172.

Jaques, A.L, Lewis, J.D., Smith, C.B., 1986. The kimberlites \& lamproites of Western Australia. Geol. Surv. Western Australia, Bull. 132, 268 p.

Jaques, A.L., Sun, S-S., Chappell, B.W., 1989. Geochemistry of the Argyle (AK1) lamproite pipe, Western Australia. In Kimberlites and related rocks, Vol. 1, Their composition, occurence, origin and emplacement (Eds J. Ross et al.), Geol. Soc. Aust. Spec. Publ., No14: 170-188.

Jaques, A.L., O’Neill, H.St.C., Smith, C.B., Moon, J., Chappell, B.W., 1990. Diamondiferous peridotite xenoliths from the Argyle (AK1) lamproite pipe, Western Australia. Contrib. Mineral. Petrol. 104, 255-276.

McDonough, W.F., Sun, S-S., 1995. The composition of the Earth. Chem. Geol. 120, 223-253.

O’Neill, C.J., Moresi, L., 2003. How long can diamonds remain stable in the continental lithosphere? Earth Plane. Sci. Lett. 213, 43-52.

Page, R.W., Sun, S-S., 1991. East Kimberley-geochronology. In yearbook of the bureau of mineral resourcesgeology and geophysics. Canberra, A.C.T.: Australia Government Publishing SERvice, p. 80.

Pearson, D.G., Irvine, G.J., Ionov, D.A., Boyd, F.R., Dreibus, G.E., 2004. Re-Os isotope systematics and platinum group element fractionation during mantle melt extraction: a study of massif and xenolith peridotite suites, Chem. Geol. 208, 29-59.

Pearson, D.G., Wittig, N., 2008. Formation of Archean continental lithosphere and its diamonds: The root of the problem. Journal of the Geological Society, London, 165, 1-20.

Pidgeon, R.T., Smith, C.B., Fanning, C.M., 1989. Kimberlite and lamproite emplacement ages in Western Australia. In Kimberlites and related rocks, Vol. 1, Their composition, occurence, origin and emplacement (Eds J. Ross et al.), Geol. Soc. Aust. Spec. Publ., No14: 369-381.

Richardson, S.H.., 1986. Latter-day origin of diamonds of eclogitic paragenesis. Nature 3122, 623-626.

Simons, F.J., Zielhuis, A., van der Hilst R.D., 1999. The deep structure of the Australian continent from surface wave tomography. Lithos 48, 17-43. 